\title{
Character Education Values on Dialogue in English Textbook Entitled Bahasa Inggris Think Globally Act Locally
}

\author{
Sella Alvionita ${ }^{1^{*}}$, Arifmiboy ${ }^{2}$ \\ ${ }^{1}$ State Institute of Islamic Studies (IAIN) Bukittinggi, Indonesia \\ ${ }^{2}$ State Institute of Islamic Studies (IAIN) Bukittinggi, Indonesia \\ ${ }^{*}$ Corresponding Author: shellaalfionita18@gmail.com
}

\begin{abstract}
This research is aimed to find out 18-character education values on dialogue in English textbook entitled "Bahasa Inggris Think Globally Act Locally" ninth grade on semester one. Design of this research is descriptive qualitative research. The instrument of this research is observation sheet. The data was collected from observation sheet to find out the 18-character education values in English textbook. The data analysis techniques used in this research were organizing and familiarizing, and (2) coding and reducing or eliminating. The result of the research showed that all the 18 character values from the 2013 Curriculum were already implemented in the book. It was found that there were 12 religiosity, 10 honesty, 3 tolerance, 2 hard work, only 1 creativity value, only 1 independence, only 1 value that is related with democracy, 7 examples that are related to the curiosity, only one nationalism and patriotism, 27 appreciation values, 14 examples that are related to the friendship and communication, 15 sentences that are related with love of peace, 2 sentences that are related with fondness of reading, 3 sentences that are related with environmental awareness, 31 sentences that are related to the social care values, there were 3 sentences that are related with responsibility values.
\end{abstract}

Keywords: textbook, 2013 curriculum, character education values

\section{INTRODUCTION}

Curriculum is a set of plans created to help teachers to keep track on what students needs to learn and what students have to learn by the end of the courses. According to Wortham (2006) that curriculum is a planned set of course that is presented to teachers to arrange teaching and learning in certain level of ages. It also means that curriculum helps teacher in facilitating them through sets of instructional materials, method of teaching, and method of assessment that has been provided within it. Those are solely conducted to help students to accomplish their needs and relevance toward learning.

The ministry of education has introduced 2013 Curriculum. The general orientation of 2013 Curriculum is to increase and improve both soft skills and hard skills which include some competencies like attitudes, skills, and knowledge. Thus, this curriculum is also considered as the integrated curriculum. This means that the soft skills and the hard skills should be accommodated in balance proportion. This is in line with the spirit proposed by the Ministry of Education and Cultures that the 2013 Curriculum is meant to improve the quality of education by balancing soft skills and hard skills through the ability of attitudes, skills, and knowledge in order to face the global challenges that continue to advance and develop (Zulfani, Irna \& Armaida, 2017). Students cannot only know the theories of the lessons but they also have to be able to practice and implement the theories as well. In a simple way, in the context of English language education, the students do not only need to be able to pass the exam that 
are mostly reading and listening and memorizing, but they need to be able to speak and write using English language.

Since the function of the curriculum is as the guidance of the system that is going on at the school, it also covers the selection of the teaching materials, including the textbook. The textbooks need to follow the curriculum as well. For example, at the time 2004 Curriculum was implemented, the text book would be adjusted with the 2004 Curriculum. As for now, since the Curriculum 2013 is used, the text books that are oriented with 2004 curriculum are no longer used. Usually, text books that are 2004 Curriculum oriented are still can be found in the library as the reference or as the additional material for the teachers. However, they are no longer actively used.

Textbook is one of the important media for teacher and students. With the help of textbook, teacher could plan teaching material systematically and efficiently as textbook provides aim and goal for each lesson. The teacher could prepare and develop learning materials and class activities effectively. Even though the textbooks are meant for the students, it could also help the teachers. The teachers could consider the material that she/he is going to teach related to the textbook. From the textbook, the teachers could develop the material in the meaningful way (Suryaman, 2006). While for student, textbook help them as reference in learning so that they are able to perform independent study beyond the classroom session. The importance of textbook in teaching and learning process makes it crucial for the teacher to select appropriate textbook for the student as there are various English books published by many publishing companies. The teacher needs to be careful in choosing the appropriate one. The content has to be in conformity with the current curriculum as well as the aim and goal for students to achieve. By owning the textbook in improves the students' achievement in learning (Suryaman, 2006). This means that owning the textbook has positive correlation with the learning achievement.

One of the learning outcomes in current curriculum is character education. The character education content in the current curriculum, the 2013 Curriculum (K-13) is based on the Ministerial Decree of Ministry of Education and Culture (MoEC) Number 81/A of 2013. Character education does not only teach the children what is right or wrong, but the character education introduces good habits so that learners understand and they are able to feel and willing to good. Character education thus brings the same mission as "akhlak" education or moral education (Khairuddin, 2017). There are eighteen characters proposed in the 2013 curriculum: spiritual, honesty, tolerance, discipline, perseverance, creativity, independence, democracy, curiosity, nationalism, patriotism, appreciation, friendliness or communication, love of peace, reading interest, environmental awareness, social awareness, and responsibility). The 18 values of this 2013 curriculum must be applied as well in the textbook that are currently used by the students. One of the important characteristics of students who need to understand by teacher as educators are talents and individual intelligence (Arifmiboy, 2016). This is one of the important things that need to be done in order to make the 2013 Curriculum becomes well-applied at the school. This research is aimed to find out 18 aspects of the character education values on dialogue in English textbook entitled "Bahasa Inggris Think Globally Act Locally" at the first semester of the ninth grade.

\section{METHOD}


The design of the research is descriptive qualitative research. According to Gay, a descriptive method is a method of research that involves collecting data in order test hypothesis or to answer question concerning correct status of the subject of the study. It means that if the research conducted a descriptive research, the research should collect the data and try to describe it based on the current status found by the researcher. This method suits with this research because this research describes the phenomena about the character education values.

In this research, the observation checklist was used to analyze the textbook of Bahasa Inggris Think Locally and Act Globally. The observation sheet was administrated in order to find out the values of character education based on the 2013 Curriculum in the textbook. The steps to collect the data were as follows: (1) determining the appropriate and relevant textbook, (2) preparing the observation checklist, (3) analyzing the textbook using the observation checklist, (4) tabulating the findings based on the character values of 2013 Curriculum.

To analyze the data, the researcher used some stages. The stages are (1) organizing and familiarizing, and (2) coding and reducing or eliminating. In the first step, researcher organized the data based on each chapter. Then, the researcher clustered the same values of the character education in every figure as familiarizing step. Next, the researcher conducted coding and reduced the data based on character education values table and eliminated some data according to the limitation of the study.

\section{FINDINGS AND DISCUSSION}

In this section, it describes and analyzes the findings based on the method. The section describes the findings and is divided into parts, description and analysis of the data based on the instrument used in this research. It was meant to find out the character values in the English textbook. There were 18 indicators that would be observed in the book, which can be viewed on the table below:

Table 1. Observation Indicators

\begin{tabular}{clc}
\hline No & Character Values & Total \\
\hline 1 & Religiosity & 4 \\
2 & Honesty & 9 \\
3 & Discipline & 1 \\
4 & Preseverance & 2 \\
5 & Creativity & 1 \\
6 & Independent & 1 \\
7 & Curiosity & 9 \\
8 & Reading Interest & 1 \\
9 & Responsibility & 7 \\
10 & Tolerance & 2 \\
11 & Democracy & 1 \\
12 & Appreciation & 18 \\
13 & Friendship and communication & 29 \\
14 & Love of Peace & 5 \\
\hline
\end{tabular}


Journal of Literature, Linguistics, and Language Teaching

Volume 1 (2) 2020

ISSN: 2746-8968

https://journal.unesa.ac.id/index.php/nld/index

\begin{tabular}{rlc}
\hline 15 & Environment Awareness & 4 \\
16 & Social Awareness & 38 \\
17 & Nationalism & 1 \\
18 & Patriotism & 1 \\
\hline
\end{tabular}

\section{Religiosity}

Based on the table above, it was found that there were four values related with religiosity indicated in the textbook. The religiosity value is indicated by the following sentence:

“Thank God, I have got an A for Math Test”. (p. 7)

The expression represents the religious values in the dialogue that shows gratitude to the good results of the test by thanking God. The authors of the textbook expect that the students have to have similar attitudes when they get good results in their test or other aspects in daily life to show gratitude and remember the God when they are happy or sad.

\section{Honesty}

According to the table above, it can be seen that there are nine values of honesty found in the textbook. One example of the expression that represents honesty is as follows:

"Udin honestly tells Edo that they were a bit late” (p. 89)

Honesty exists not only in what you say, but also in the things you do. If you act differently with what you think or feel, basically you are being dishonest. The effect of the honesty on others may tell you how to act in any situation (Stevensen,20016). The authors present the value of honesty in the dialogue in order to tell the students that having to be honesty for everyone in any situation.

\section{Discipline}

According to the table above, it was found that there was one value related with discipline in the textbook. One of the sentences that indicates that value is as follows:

\section{"Please go back to work so that we can finish the text before lunch" (p. 30)}

Discipline people are able to control their impulses and focus their energy to accomplish things without anybody telling them to. They apply rules for themselves to get where they want to go (Stevensen,2006). The authors present the discipline values in dialogue that indicate to work on time based on the schedule. The dialogue tells the students that they need to follow the rules and regulations when they are performing their jobs. 
Journal of Literature, Linguistics, and Language Teaching

Volume 1 (2) 2020

ISSN: 2746-8968

https://journal.unesa.ac.id/index.php/nld/index

Based on the table above, it was found that there were two values related with perseverance or hard work that were indicated in the textbook. The following is the example:

"... and I have practiced every day for the last two months with my dad." (p. 4)

The authors present the perseverance character in the dialogue, showing how the person has to practice every day for the last two months in order to achieve something. Such dialogue has purpose to tell the students that they need to show their hard work and be resilient to achieve what they want or dream of.

\section{Creativity}

According to the table above, it was found that there was only one value of creativity in the textbook. The value is proven by a dialogue that shows creativity:

"Let's stop working for a while to get some fresh air outside” (p. 112)

Creativity is defined as bringing something new into being which could be almost anything: an idea, a painting, a piece of music, or an invention. The important thing is that it is new and original to the creator (Stevensen, 2006). The authors present the value of creativity by having certain moment what is called as an idiom of "getting some fresh air outside". The idiom shows the importance of looking for something new in order to be creative.

\section{Independence}

According to the table above, it was found that there was only one value related with independence in the textbook. The value is indicated by one sentence as follows:

"Everyone of us will handwrite our reflection on our learning process. We will use English or Bahasa Indonesia” (p. 130)

From the dialogue above, the authors want to make the students have independent value by trying to do everything with their own ability.

\section{Curiosity}

Curiosity is a good character for the students. Based on table above, there were nine examples of expressions related to the curiosity value. The following is one example of the expression found in the textbook:

"Why does not she live with her grandparents?” (p. 111)

From the dialogue above, it shows that students may need to ask and explore a new information from everyone in order to get valid or reliable answer. This kind of values of important to help students avoid from hoax in current situation.

\section{Reading Interest}


Journal of Literature, Linguistics, and Language Teaching

Volume 1 (2) 2020

ISSN: 2746-8968

https://journal.unesa.ac.id/index.php/nld/index

Based on the observation in the textbook, it can be found one sentence that represents reading interest or fondness of reading. One example of the expression showing reading interest is as follows:

"When I saw her, she was reading a novel, now she is reading a novel, next time she will be reading a novel too" (p. 81)

The dialogue emphasizes the repeated characterization of the person of having reading interest values likes reading novels. Such character shows that reading is a good character in order to increase our knowledge.

\section{Responsibility}

Based on the table above, it can be seen that there were seven sentences related with the value of responsibility. One of the examples is as follows:

"I am sorry I didn't hear your call. I was watering the front yard. Here is your dictionary I don't forget to bring it" (p. 96)

Being responsible means that you answer for your actions. If you say you will do something, you must follow through on your promise. If you make a mistake, you should admit it and take responsibility for the consequences (Stevensen, 2006). From the dialogue above, the author expects the students to have responsible character in every action they do.

\section{Tolerance}

Based on the table above, it was found that there were two values of tolerance in the textbook. The following is the example of the value:

“It's fine, Edo. So far you have only missed one meeting." (p. 92)

The purpose of the authors from the dialogue is that they want to tell the students that they should have tolerant understanding to their friends in order to show their awareness.

\section{Democracy}

Based on the table above, it was found that there was only one value that is related with democracy. It was the students' plan to go to the orphanage, instead of deciding it by his own self, Edo asked his friends about his plan by stating

"Why don't we...?” (p. 109)

From the dialogue above, the authors want to tell the students that we have to ask someone's opinion and respect about it. If the students want to decide something, they have to discuss it firs; that is democracy.

\section{Appreciation}

According to the table above, it was found that there were 27 appreciation values in the textbook. The following sentence indicates the value of appreciation:

"Congratulations, Siti. You deserve it. Your mom and your dad must be proud of you”. (p. 3) 
Journal of Literature, Linguistics, and Language Teaching

Volume 1 (2) 2020

ISSN: 2746-8968

https://journal.unesa.ac.id/index.php/nld/index

From the dialogue above, the authors expect the students to have to appreciate and respect the others on their achievement.

\section{Friendliness or Communication}

Based on table above, there were 29 examples that were related to the friendship and communication value. The example was:

"Happy birthday Udin. You are a big boy now. I am proud of you". (Bahasa Inggris Think Globally Act Locally, page 19)

From the dialogue above, the authors want to tell the students that communication is important in our life in order to create peace life.

\section{Love of Peace}

Based on the observation on the textbook, it can be found 5 sentences that are related with love of peace. One of the examples is as follows:

“Thank you, dad. I am proud of you” (p. 81)

From the dialogue above, love of peace is also important in our life, we have to love of peace to people around us.

\section{Environment Awareness}

Based on the table above, there were four sentences that are related with the environmental awareness. One of them is the conversation between two students that will not let the spilled milk mess the floor, so that they clean the floor. This can be taken as the environmental awareness.

\section{Social Awareness}

According to the table above, there were 38 sentences that are related with the value of social awareness. It is considered as the value which is most frequently provided by the textbook. The following is the example of expression that promotes social awareness:

"I think Riri is the most interesting orphan I have ever known. Unfortunately, I didn't have any chance to talk to her personally."

"Can you tell me how she has come to the orphan home" (p. 119)

The authors present values of the social aware in the dialogues that they want to tell the students they should be aware with the others and help each other who needs a help. Caring is something most people do in small ways every day. A friend has a problem, so we listen and give advice (Stevenson, 2006)

\section{Sense of Nationalism and Patriotism}

Based on the table above, it was found that value of nationalism and patriotism is only found in one dialogue in the textbook. The following is the example:

"I will take part in a bite race to celebrate independence day" (p. 8) 
Journal of Literature, Linguistics, and Language Teaching

Volume 1 (2) 2020

ISSN: 2746-8968

https://journal.unesa.ac.id/index.php/nld/index

From the dialogue above, the authors describe one way to celebrate the Independence Day as part of nationalism. It is expected that the students should have a soul of nationalism and patriotism.

Based on the finding that was gathered from the analysis through the textbook, it can be found that all the 18 values of character education from the 2013 Curriculum have been already accommodated in the textbook. It was found that there were four values of religiosity, nine of honesty, one discipline, two perseverance, only one value of creativity, one value of independence, nice examples related to curiosity, one expression related with reading interest, seven sentences related with responsibility, two related with tolerance, only one value of democracy, 18 appreciation values, 29 examples that were related to the friendliness and communication, five sentences related with love of peace, four sentences related with environmental awareness, 38 sentences that were related to the social care values, and only one nationalism and patriotism.

Social awareness becomes the most frequent values found by the textbook amounting to 38 dialogues. It can be assumed that the government has an expectation from the society to have these values which can give the influence for the students to help each other and care with the society. On the other hand, the least frequent values were patriotism, nationalism, democracy, creativity, independence, discipline and reading interest.

From the explanation above, it can be concluded that the textbook which designed for ninth grade students (secondary education) is already appropriate as the teaching material to develop character education values of the students.

The findings indicate that the book already accommodates the character values that were suggested by the 2013 Curriculum as stated by Permana (2018) saying that the character education content in the current curriculum, the 2013 Curriculum (K-13) is based on the Ministerial Decree of Ministry of Education and Culture (MoEC) Number 81/A 2013. There are eighteen characters that proposed in the 2013 curriculum: spiritual, honesty, tolerance, discipline, perseverance, creativity, independence, democracy, curiosity, nationalism, patriotism, appreciation, friendliness or communication, love of peace, reading interest, environmental awareness, social awareness, and responsibility.

\section{CONCLUSSION AND SUGGESTION}

Based on the findings the research about the analysis of character education values on 2013 Curriculum English textbook entitled "Bahasa Inggris Think Globally Act locally", it can be concluded that all the 18 character values from the 2013 Curriculum have been already accommodated in the textbook. Social awareness becomes the highest frequent values that is found in the English textbook which is integrated into 38 sentences and dialogues in the textbook. It can be seen that the government has an expectation for these values which can give the influence for the students to help each other in the society.

Concerning with the conclusion above, the following suggestion provides benefits for teachers and future researchers. For the teachers, it is expected that teachers be careful and selective in choosing the textbook that help the students in teaching and learning activities, particularly textbook that accommodates character values; they should choose the textbook that contain good character in the material. 
Journal of Literature, Linguistics, and Language Teaching

Volume 1 (2) 2020

ISSN: 2746-8968

https://journal.unesa.ac.id/index.php/nld/index

The authors would like to thank and grateful to the family, advisor, and board of examiners for their contribution and guideline to complete this article.

\section{REFERENCES}

Arifmiboy. (2016). Multiple Intelligence: Mengoptimalkan Kecerdasan Anak Sebagai Upaya Dalam Mempersiapkan Generasi Emas Masa Depan. Procedding International Seminar on Education

Andrianti, Irna., Sesmiarni, Zulfani, \& Armanida. (2017). Implementasi Pendekatan Scientific Pada Mata Pelajaran Pendidikan Agama Islam Di Sekolah Dasar, Journal of Education Studies Vol 2, No 2, Juli-Desember, pp. 147

Gay, L. R. (2000). Educational Research: Competencies for Analysis and Application 6th Edition. NewJersey: Prentice Hall.

Kementrian Pendidikan dan Kebudayaan. (2013). Kerangka Dasar dan Struktur Kurikulum Kementrian Pendidikan dan Kebudayaan. (2013). Bahasa Inggris Think Globally Act Locally. Khairuddin. (2017). Pendidikan Karakter Berbasis Islam di Era Global. Proceeding of Internasional Seminar on Tarbiyah, Insititut Agama Islam Negeri Bukittinggi.

Permana. (2018). Portraying Character Education in Junior High School Textbooks of the 2013 Curriculum. Journal of English Language Studies Volume 3 Number 2 (2018) 245-258.

Stevensen, Nancy. (2006). Young person Character Education Hand book. JIST Publishing

Suryaman, Maman. (2006). Dimensi-dimensi Kontektual di dalam Penulisan Buku Tels Pelajaran. Yogyakarta: UNY.

Wortham. (2006). Early Childhood Curriculum - Developmental Bases for Learning and Teaching. New Jersey: Pearson Education Inc. 